E-JURNAL EKONOMI DAN BISNIS UNIVERSITAS UDAYANA
Available online at https://ojs.unud.ac.id/index.php/EEB/index
Vol. 10 No. 7, July 2021, pages: 626-641
e-ISSN: 2337-3067

\title{
DETERMINAN TINGKAT KEMISKINAN DI KOTA BANDUNG
}

\section{Bayu Kharisma ${ }^{1}$ Teguh Santoso $^{2}$}

Article history:

Submitted: 18 Februari 2021

Revised: 9 April 2021

Accepted: 29 April 2021

\section{Keywords:}

Ousehold Poverty Status;

Ordered Logit;

Demographic;

Economic;

Social Characteristics;

\section{Kata Kunci:}

Status Kemiskinan Rumah Tangga;

Ordered Logit;

Karakteristik Demografi;

Ekonomi;

Sosial;

\section{Koresponding:}

Departemen Ilmu

Ekonomi,Universitas

Padjadjaran, Jawa Barat,

Indonesial

Email:

bayu.kharisma@unpad.ac.id ${ }^{l}$

\section{Abstract}

This study aims to find the determinants of household poverty status in the city of Bandung by using the National Socioeconomic Survey (Susenas) of March 2018 Expenditure Consumption in Bandung. The methodology used is an ordered logit regression model. The results showed that the demographic characteristics variables that had a significant and positive effect on the poverty status of households in the city of Bandung were female household heads, marital head households and household size and dependency burden. Meanwhile, economic characteristics, namely household access to the internet, ownership of mobile phones (HP), ownership of one's own residence, and access to business credit have a negative and significant effect on household poverty status in the city of Bandung. Furthermore, social characteristics that negatively affect the status of household poverty in the city of Bandung are variable levels of school education as measured by the years of schooling.

Abstrak
Penelitian ini bertujuan untuk mengetahui determinan status
kemiskinan rumah tangga di Kota Bandung dengan menggunakan data
Survei Sosial Ekonomi Nasional (Susenas) Konsumsi Pengeluaran Maret
2018 Kota Bandung. Metodologi yang digunakan adalah model regresi
ordered logit. Hasil penelitian menunjukkan bahwa variabel karakteristik
demografi yang berpengaruh signifikan dan positif terhadap status
kemiskinan rumah tangga di Kota Bandung adalah kepala rumah tangga
berjenis kelamin perempuan, kepala rumah tangga berstatus kawin dan
ukuran rumah tangga dan beban ketergantungan. Sementara itu,
karakteristik ekonomi yaitu akses rumah tangga terhadap internet,
kepemilikan handphone (HP), kepemilikan rumah tinggal sendiri, dan akses
terhadap kredit usaha berpengaruh negatif dan signifikan terhadap status
kemiskinan rumah tangga di Kota Bandung. Selanjutnya, karakteristik
sosial yang berpengaruh negatif terhadap status kemiskinan rumah tangga
di Kota Bandung yaitu variabel tingkat pendidikan sekolah yang diukur dari
lama sekolah.

Departemen Ilmu Ekonomi, Universitas Padjadjaran, Jawa Barat, Indonesia ${ }^{2}$ 


\section{PENDAHULUAN}

Kemiskinan merupakan permasalahan pembangunan terutama di negara-negara berkembang (Todaro \& Smith, 2011; Haughton \& Khandker, 2012). Kemiskinan juga didefinisikan sebagai kondisi keterbatasan kemampuan untuk memenuhi kebutuhan hidup secara layak seperti keterbatasan dalam pendapatan, keterampilan, kondisi kesehatan, penguasaan aset ekonomi, ataupun akses informasi (Isdijoso, Suryahadi \& Akhmadi, 2016). Komitmen dunia internasional dalam penanggulangan kemiskinan tertuang dalam Sustainable Development Goals (SDGs) sebagai kelanjutan Millenium Development Goals (MDGs) yang di sepakati oleh 193 negara pada September 2015 (SMERU, 2017). Tujuan pertama SDGs, penanggulangan kemiskinan dan kelaparan diakui sebagai permasalahan utama dalam pembangunan global dengan sasaran mengurangi kemiskinan secara berkelanjutan dan selamanya (Griggs et al., 2013; Kates, Parris, \& Leiserowitz, 2005; Moran et al., 2008; Sachs, 2012). Adapun komitmen Pemerintah Indonesia tertuang dalam rencana pembangunan jangka menengah nasional (RPJMN) 2014-2019, dimana Indonesia menargetkan penurunan tingkat kemiskinan pada tahun 2019 sebesar 7-8\%.

Komitmen yang sama dilakukan oleh Pemerintah Daerah, khususnya di Kota Bandung. Permasalahan kemiskinan yang terjadi di Indonesia merupakan akumulasi dari kemiskinan yang berada di provinsi, dimana ujung dari kemiskinan tersebut berada di kabupaten/kota. Kota Bandung sebagai salah satu kota di Indonesia yang memiliki jumlah penduduk sangat banyak dan penduduk miskin cukup tinggi (dalam hal ini adalah penduduk yang berada dibawah Garis Kemiskinan). Jumlah penduduk miskin di Kota Bandung pada tahun 2018 adalah sebanyak 89,38 ribu orang dari total penduduk Kota Bandung. Jumlah ini mengalami penurunan jika dibandingkan dengan tahun 2017 yaitu 103,98 ribu orang. Sementara itu, apabila dibandingkan dengan kota-kota lain di Jawa Barat, Kabupaten Bogor menempati posisi pertama dengan jumlah penduduk miskin terbanyak yaitu sebesar 415,0 ribu jiwa, sedangkan yang paling sedikit terdapat di Kota Banjar sebesar 10,4 ribu jiwa. Namun, jika dibandingkan jumlah penduduk pada masing-masing kabupaten/kota, tingkat kemiskinan terendah ada di Kota Depok yaitu sebesar 2,14 persen, sementara yang tertinggi di Kota Tasikmalaya sebesar 12,71 persen.

\section{Grafik 1.}

\section{Jumlah Penduduk Miskin di Kabupaten dan Kota di Jawa Barat Tahun 2018 (dalam 000)}

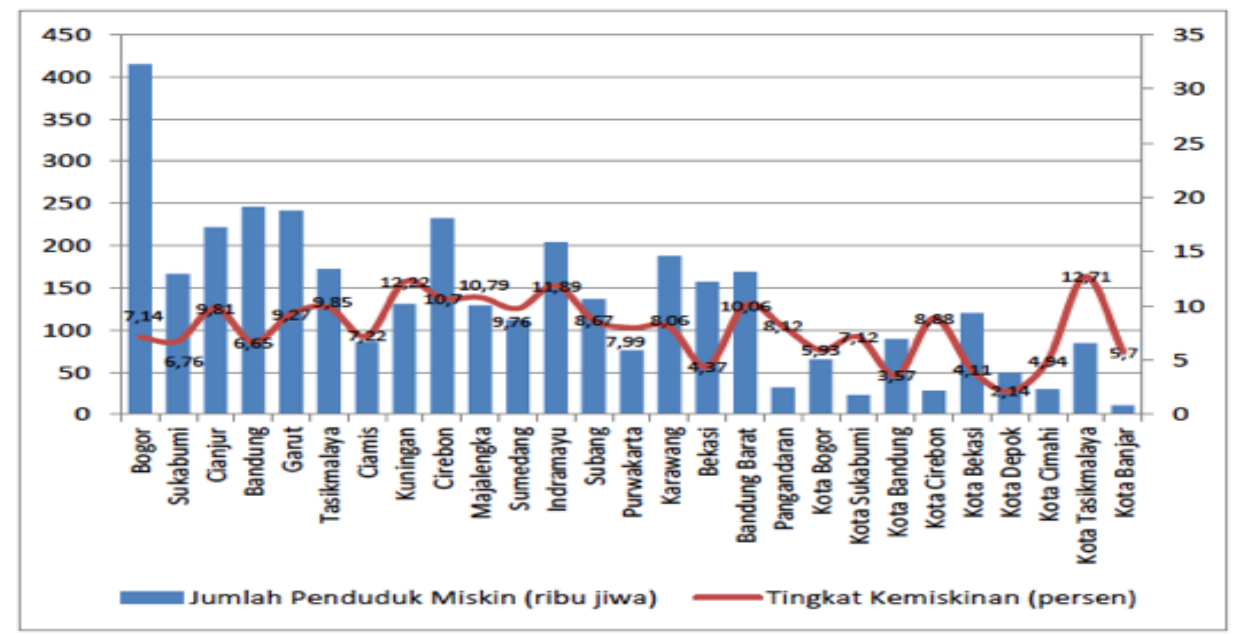

Sumber: Susenas, 2018 
Jumlah penduduk miskin selama enam belas tahun terakhir cenderung fluktuatif, sedangkan dari sisi tren mengalami peningkatan (lihat Grafik 2). Pada periode tahun 2018, jumlah penduduk miskin di Kota Bandung sebesar 89,38 ribu orang atau menurun 14,04 persen dibanding tahun 2017 yang mencapai 103,98 ribu jiwa. Sementara itu, apabila ditinjau dari penurunan kemiskinan pada periode tahun 2013-2018, angka kemiskinan secara rata-rata mampu turun sebesar 24,06 persen per tahun. Penurunan jumlah orang miskin tersebut tidak lepas dari adanya pemberian bantuan pemerintah melalui Program Keluarga Harapan (PKH) dan pendampingan Tenaga Kerja Sosial Kecamatan (TKSK) yang telah berjalan baik serta tingginya kesadaran masyarakat Kota Bandung untuk saling membantu sehingga memberikan berkontribusi terhadap penurunan angka kemiskinan (Bappenas, 2014).

\section{Grafik 2.}

Jumlah Penduduk Miskin di Kota Bandung, 2002-2018 dalam (000)

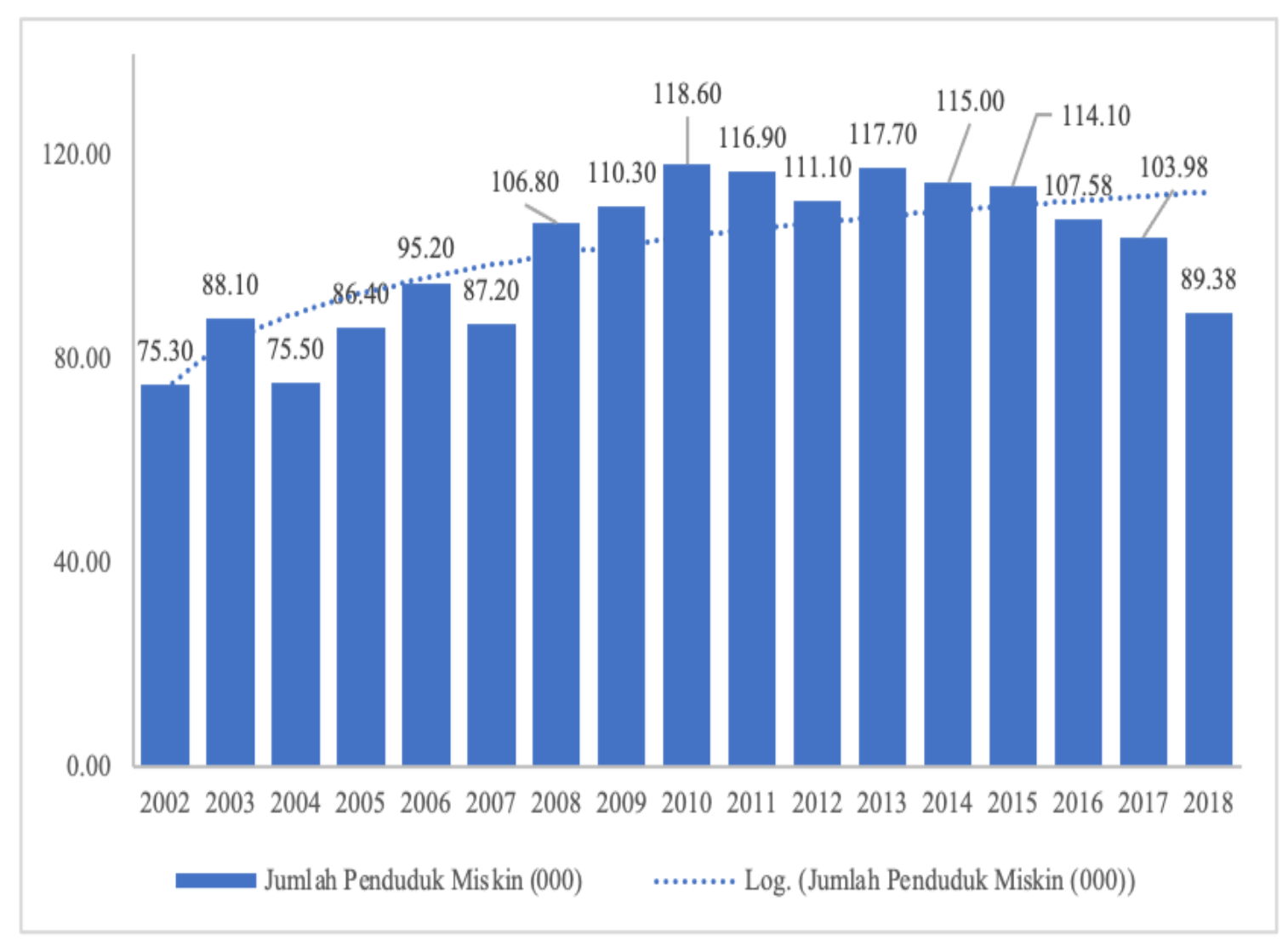

Sumber: BPS Provinsi Jawa Barat 2018, diolah

Sementara itu, garis kemiskinan (poverty line) menunjukkan jumlah rupiah minimum yang dibutuhkan untuk memenuhi kebutuhan pokok minimum makanan setara dengan 2100 kilo kalori per kapita per hari dan kebutuhan pokok bukan makanan. Besar kecilnya jumlah penduduk miskin sangat dipengaruhi oleh garis kemiskinan, karena penduduk miskin adalah penduduk yang memiliki rata-rata pengeluaran per kapita per bulan di bawah garis kemiskinan. 
Garis kemiskinanan di Kota Bandung selama periode 2010-2018 mempunyai pola semakin meningkat dengan rata-rata sebesar Rp. 358.527 (lihat Grafik 3). Pembentuk garis kemiskinan di Kota Bandung masih didominasi oleh kelompok pengeluaran bahan makanan, antara lain beras, bawang merah, bawang putih, daging ayam ras, cabe merah, bayam, jagung manis dan lainnya yang mencapai 3,76\% selama bulan November-Desember 2018. Oleh karena itu, tidak dapat dipungkiri bahwa melakukan pengawasan atau mengawal stabilitas harga penyumbang garis kemiskinan akan membantu memperlambat laju pertumbuhan garis kemiskinan di Kota Bandung.

\section{Grafik 3.}

\section{Garis Kemiskinan (Rp/Kapita/Bulan) Kota Bandung, 2010-2018 (Rupiah)}

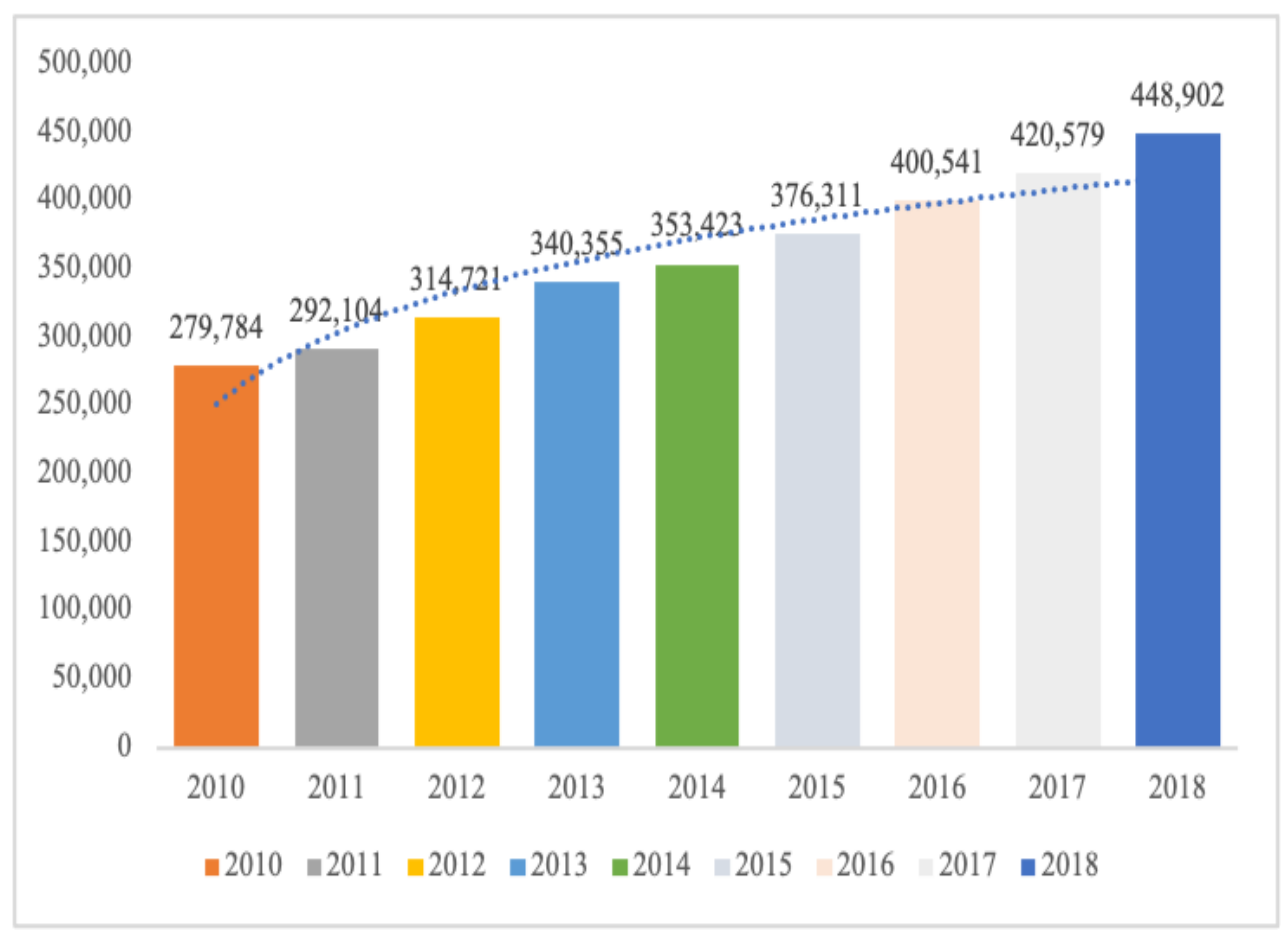

Sumber: BPS Provinsi Jawa Barat 2018, diolah

Upaya untuk menanggulangi permasalah kemiskinan di Kota Bandung terus dilakukan berbagai pihak, khususnya pemerintah Kota Bandung. Selain melalui peningkatan kondisi perekonomian secara umum perlu juga usaha-usaha secara kontinu untuk mengurangi kemiskinan di Kota Bandung. Salah satu usahanya adalah dengan melakukan penelitian tentang kemiskinan dengan pendekatan mikro pada tingkat rumah tangga. Penelitian ini diharapkan dapat memberikan gambaran secara lebih mendalam mengenai kondisi individu dan rumah tangga miskin tersebut sehingga dapat diketahui determinan yang mempengaruhi kemiskinan rumah tangga di Kota Bandung.

Sepanjang pengetahuan penulis, penelitian mengenai determinan kemiskinan rumah tangga dalam konteks Kota Bandung selama tahun 2018 masih belum dilakukan. Penelitian sebelumnya mengenai determinan kemiskinan rumah tangga, seperti yang dilakukan Mok., et al (2007) dan Sekhampu (2013) hanya menggunakan dua kategori status kemiskinan yaitu miskin dan tidak miskin. Sementara itu, yang dilakukan Geda et al. (2005), Epo (2010) dan Cho \& Kim (2017) menggunakan tiga kategori status kemiskinan yaitu sangat miskin, miskin, dan tidak miskin. Selain itu, sesuai dengan Tujuan Pembangunan Berkelanjutan atau SDGs (Sustainable Development Goals) yang telah 
disepakati oleh 193 negara anggota PBB pada tahun 2015 yang menyatakan no poverty sebagai poin pertama prioritasnya yang berarti bahwa dunia bersepakat untuk meniadakan kemiskinan dalam bentuk apapun di seluruh penjuru dunia yang diharapkan dapat terwujud sampai tahun 2030 (Panuluh \& Fitri, 2016).

Kota Bandung sebagai bagian dari pencapaian SDGs tersebut dan dengan kondisi pertumbuhan ekonomi yang baik diharapkan dapat menjadi pelopor bagi terciptanya no poverty. Guna tercapainya tujuan tersebut maka salah satu upaya yang dilakukan penulis adalah melakukan penelitian mengenai determinan kemiskinan rumah tangga di Kota Bandung secara lebih mendalam dengan menggunakan lima kategori status kemiskinan dari BPS yaitu sangat miskin, miskin, hampir miskin, rentan miskin, dan tidak miskin.

\section{METODE PENELITIAN}

Data yang digunakan dalam penelitian ini adalah data sekunder yang bersumber dari Badan Pusat Statistik (BPS), yaitu data hasil olah Survei Sosial Ekonomi Nasional (Susenas) Konsumsi Pengeluaran Maret 2018 Kota Bandung. Data Susenas ini mencakup keadaan sosial ekonomi rumah tangga seperti demografi, pendidikan, kesehatan, pekerjaan, fasilitas perumahan, dan pengeluaran rumah tangga. Unit analisis yang digunakan dalam penelitian ini adalah rumah tangga sebanyak 9.97 sampel dan individu sebanyak 3.428 sampel. Garis kemiskinan yang digunakan adalah Garis Kemiskinan BPS untuk Kota Bandung tahun 2018 yaitu sebesar Rp 448.902,-.

Metode analisis yang digunakan untuk menentukan determinan status kemiskinan rumah tangga pada penelitian ini mengikuti metode yang digunakan sebelumnya yaitu metode ordered logit (Geda et al, 2005; Epo, 2010; Bogale., Hagedorn \& Korf, 2005). Metode regresi ordered logit bertujuan untuk menjelaskan determinan pada sebuah rumah tangga dengan kategori sangat miskin, miskin, hampir miskin, rentan miskin, atau tidak miskin. Dalam metode ini diasumsikan bahwa probabilitas sebuah rumah tangga berada pada kategori kemiskinan tertentu ditentukan oleh variabel respon yang mendasarinya (underlying respone variable) yang menangkap status ekonomi sebenarnya dari sebuah rumah tangga. Model yang digunakan untuk menganalisis determinan kemiskinan rumah tangga di Kota Bandung adalah berikut ini.

$$
\text { miskin }_{i}=\beta_{0}+\beta_{1} \text { Demografi }_{i}+\beta_{2} \text { Ekonomi }_{i}+\beta_{3} \text { Sosial }_{i}+\varepsilon_{i}
$$

Dimana miskin adalah status kemiskinan rumah tangga $(5=$ sangat miskin; $4=$ miskin; $3=$ hampir miskin; 2 = rentan miskin; 1 = tidak miskin). Variabel karakteristik demografis adalah usia kepala rumah tangga (tahun), usia kepala rumah tangga dikuadratkan (tahun), jenis kelamin kepala rumah tangga (1=perempuan; 0=laki-laki), status perkawinan kepala rumah tangga (1=kawin; $0=$ lainnya) dan ukuran rumah tangga (orang) dan $\mathrm{e}_{\mathrm{i}}$ adalah error term. Sementara itu, karateristik ekonomi adalah status kepala rumah tangga bekerja, lapangan usaha perdagangan, memiliki akses internet, status kepemilikan smartphone (HP), tempat tinggal milik sendiri, memiliki akses kredit usaha. Terakhir, karateristik sosial adalah lama sekolah kepala rumah tangga, kepala rumah tangga memiliki jaminan kesehatan dan status kepala rumahtangga migran. 


\section{HASIL DAN PEMBAHASAN}

Dalam menganalisa determinan tingkat kemiskinan di Kota Bandung, kajian ini menggunakan data cross section tingkat rumah tangga hasil Survei Sosial Ekonomi Nasional (Susenas) di Kota Bandung 2018. Sementara itu, status rumah tangga miskin diklasifikasikan ke dalam lima status kemiskinan, yaitu sangat miskin, miskin, hampir miskin, rentan miskin, dan tidak miskin. Adapun kriterianya sebagai berikut : (a) sangat miskin, jika pengeluaran perkapita/bulan < 0,8 GK; (b) miskin, jika 0,8 GK $\leq$ pengeluaran perkapita/bulan < $1 \mathrm{GK}$; (c) hampir miskin, jika $1 \mathrm{GK} \leq$ pengeluaran perkapita/bulan < 1,2 GK; (d) rentan miskin, jika 1,2 GK $\leq$ pengeluaran perkapita/bulan $\leq$ 1,6 GK dan ; (d) tidak miskin, jika pengeluaran perkapita/bulan > 1,6 GK.

Jumlah sampel yang termasuk kateogori rumah tangga miskin dalam susenas kota Bandung 2018 yaitu 977 rumah tangga (lihat Tabel 1). Pada karateristik demografi menunjukkan bahwa usia kepala rumah tangga rata-rata berusia 47 tahun dengan usia paling muda 18 tahun dan paling tua adalah 91 tahun. Sementara itu, kepala rumahtangga yang berjenis kelamin perempuan sangat kecil yaitu 17,9 persen dan sisanya 82,1 persen laki-laki. Umumnya, kepala rumahtangga di Kota bandung sudah menikah yang mencapai $72,5 \%$. Ukuran rumah tangga ditunjukkan oleh jumlah anggota rumah tangga rata-rata sebanyak 3 orang, dimana dalam satu rumah tangga paling sedikit ada 1 orang anggota rumah tangga dan paling banyak ada 12 orang anggota rumah tangga. Sementara itu, dari karateristik ekonomi menunjukkan bahwa status kepala rumahtangga yang sudah bekerja mencapai $76,4 \%$ dan yang bekerja pada lapangan usaha di sektor perdagangan besar dan eceran, reparasi mobil dan sepeda motor hanya 2 persen. Selama periode pengamatan bulan Maret 2018, rumahtangga yang memiliki akses internet di Kota Bandung rata-rata cukup besar yaitu lebih dari 50\% dan umumnya memiliki Smartphone (HP) yaitu sebesar 84,3\%. Sementara itu, rumah tangga yang memiliki tempat tinggal miliki sendiri selama periode pengamatan 2018 mencapai 59,8\%. Selain itu, rata-rata kepala rumahtangga yang memiliki akses kredit usaha yang cukup rendah yaitu sebesar 34,2 persen.

Tabel 1.

Statistik Deskriptif

\begin{tabular}{|c|c|c|c|c|c|}
\hline & Obs & Mean & SD & Min & Max \\
\hline \multicolumn{6}{|l|}{ Variabel Karakteristik Demografi } \\
\hline Usia KRT & 997 & 47,327 & 14,829 & 18 & 91 \\
\hline Usia KRT dikuadratkan & 997 & 2459,520 & 1458,536 & 324 & 8281 \\
\hline Jenis Kelamin KRT (1=Perempuan) & 997 & 0,179 & 0,383 & 0 & 1 \\
\hline Perkawinan KRT (1=kawin) & 997 & 0,725 & 0,447 & 0 & 1 \\
\hline Ukuran Rumah Tangga & 997 & 3,438 & 1,658 & 1 & 12 \\
\hline Beban Ketergantungan & 997 & 11,735 & 32,200 & 0 & 100 \\
\hline \multicolumn{6}{|l|}{ Variabel Karakteristik Ekonomi } \\
\hline Status KRT (1=bekerja) & 997 & 0,764 & 0,425 & 0 & 1 \\
\hline Lapangan Usaha ( $1=$ perdagangan $)$ & 997 & 0,002 & 0,045 & 0 & 1 \\
\hline Akses Internet (1=ya) & 997 & 0,634 & 0,482 & 0 & 1 \\
\hline Status Kepemilikan HP (1=punya) & 997 & 0,843 & 0,364 & 0 & 1 \\
\hline Tempat Tinggal ( $1=$ milik sendiri $)$ & 997 & 0,598 & 0,491 & 0 & 1 \\
\hline Akses Kredit Usaha $(1=y a)$ & 997 & 0,342 & 0,475 & 0 & 1 \\
\hline \multicolumn{6}{|l|}{ Variabel Karakteristik Sosial } \\
\hline Lama Sekolah KRT (tahun) & 997 & 10,791 & 3,895 & 0 & 16 \\
\hline Jaminan Kesehatan (1=punya) & 997 & 0,859 & 0,349 & 0 & 1 \\
\hline Status KRT (1=migran) & 997 & 0,041 & 0,199 & 0 & 1 \\
\hline$N$ & 997 & & & & \\
\hline
\end{tabular}

Sumber : Susenas 2018, diolah 
Pendidikan kepala rumah tangga dilihat dari lama sekolah (years of schooling) kepala rumah tangga tersebut. Lama sekolah di klasifikasikan mulai dari 0 tahun sampai 16 tahun, dengan 0 tahun menunjukkan tidak/belum pernah bersekolah. Satu tahun sampai dengan enam tahun berada pada jenjang SD atau sederajat. Tujuh tahun sampai dengan sembilan tahun berada pada jenjang SMP atau sederajat. Sepuluh tahun sampai dengan dua belas tahun berada pada jenjang SMA atau sederajat, sedangkan tiga belas tahun sampai dengan enam belas tahun berada pada jenjang Perguruan Tinggi. Dalam hal ini, diketahui bahwa rata-rata lama sekolah kepala rumah tangga sampel adalah 10,791 tahun. Hal ini mengindikasikan bahwa rata-rata pendidikan terakhir kepala rumah tangga berada pada jenjang pendidikan SMA atau setara SMA. Selain itu, rata-rata kepemilikan jaminan kesehatan di Kota Bandung sangat tinggi yang mencapai 85,9 persen, sedangkan rata-rata status kepala rumah yang memoiliki jaminan kesehatan yatu hanya 9 persen. Terakhir, status kepala rumahtangga sebagai migran cukup kecil yaitu 4 persen.

Pada karakteristik demografi (lihat Tabel 2) menunjukkan bahwa rata-rata usia kepala rumah tangga yang berkategori sangat miskin adalah 47 tahun, miskin yaitu 42 tahun, hampir miskin yaitu 46 tahun, rentan miskin yaitu 47 tahun, dan yang berkategori tidak miskin yaitu 47 tahun. Ratarata kepala rumah tangga yang berjenis kelamin perempuan paling besar berada pada kategori miskin yaitu sebesar 29\%, sedangkan untuk kategori rentan miskin, hampir miskin, miskin, dan sangat miskin berada dibawah $21 \%$. Kepala rumah tangga dengan status kawin paling banyak berada pada kategori tidak miskin yaitu $12 \%$. Adapun, ukuran rumah tangga paling banyak berada pada rumah tangga sangat miskin yaitu rata-rata memiliki 5 anggota rumah tangga. Sedangkan yang paling sedikit berada pada rumah tangga tidak miskin yaitu rata-rata memiliki 3 anggota rumah tangga. Menurut BPS, anggota rumah tangga adalah semua orang yang biasanya tinggal dan makan di rumah tangga ini mulai dari kepala rumah tangga, pasangannya, anak yang belum menikah, anak yang sudah menikah, menantu, cucu, orang tua/mertua, famili lain, pembantu, dan lainnya. Selanjutnya, beban ketergantungan paling tinggi terdapat pada rumah tangga sangat miskin yang mencapai $30 \%$.

Tabel 2.

Statistik Deskriptif Karakteristik Demografi

\begin{tabular}{lllccccc}
\hline \hline $\begin{array}{c}\text { Status } \\
\text { Kemiskinan }\end{array}$ & $\begin{array}{l}\text { Sum } \\
\text { stats }\end{array}$ & $\begin{array}{c}\text { Usia } \\
\text { KRT } \\
\text { (tahun) }\end{array}$ & $\begin{array}{c}\text { Usia } \\
\text { KRT } \\
\text { dikuadratkan }\end{array}$ & $\begin{array}{c}\text { Jenis } \\
\text { Kelamin KRT } \\
\text { (1=perempuan) }\end{array}$ & $\begin{array}{c}\text { Status } \\
\text { Perkawinan } \\
\text { KRT } \\
\text { (1=kawin) }\end{array}$ & $\begin{array}{c}\text { Ukuran } \\
\text { Rumah } \\
\text { Tangga }\end{array}$ & $\begin{array}{c}\text { Beban } \\
\text { Ketergantungan }\end{array}$ \\
\hline \hline Tidak Miskin & mean & 47,572 & $2.497,464$ & 0,193 & 0,116 & 3,243 & 12,799 \\
Rentan & sd & 15,319 & $1.505,941$ & 0,395 & 0,320 & 1,591 & 33,428 \\
Miskin & mean & 46,704 & $2.305,155$ & 0,127 & 0,014 & 4,085 & 5,634 \\
Hampir & mean & 11,209 & $1.071,278$ & 0,335 & 0,119 & 1,401 & 23,221 \\
Miskin & sd & 11,930 & $1.091,047$ & 0,029 & 0,000 & 4,706 & 5,882 \\
Miskin & mean & 41,800 & $1.894,867$ & 0,171 & 0,000 & 1,851 & 23,883 \\
Sangat & sd & 12,577 & $1.114,616$ & 0,289 & 0,000 & 4,733 & 0,000 \\
Miskin & mean & 45,732 & $2.255,195$ & 0,098 & 0,000 & 2,282 & 0,000 \\
Total & sd & 12,958 & $1.399,159$ & 0,208 & 0,000 & 4,780 & 9,756 \\
& mean & 47,327 & $2.459,520$ & 0,179 & 0,090 & 1,475 & 30,041 \\
Sul & 14,829 & $1.458,536$ & 0,383 & 0,298 & 1,658 & 11,735 \\
\hline
\end{tabular}

Sumber : Susenas 2018, diolah

Karakteristik ekonomi dalam penelitian ini meliputi rata-rata status ketenagakerjaan kepala rumah tangga, rata-rata lapangan usaha/pekerjaan kepala rumah tangga di sektor utama yaitu sektor perdagangan besar dan eceran, reparasi mobil dan sepeda motor, rata-rata akses terhadap internet, rata- 
rata kepemilikan hand phone, rata-rata status kepemilikan rumah tinggal, dan rata-rata akses terhadap kredit usaha (lihat Tabel 3). Rata-rata kepala rumah tangga yang berstatus bekerja pada rumah tangga tidak miskin sebanyak 75\%, sedangkan rata-rata lapangan usaha utama kepala rumah tangga di sektor perdagangan besar dan eceran, reparasi mobil dan sepeda motor pada semua status kemiskinan rumah tangga yaitu tidak miskin sebanyak 21\%, rentan miskin 29\%, hampir miskin 35\%, miskin 33\%, dan sangat miskin $32 \%$.

Kepala rumah tangga tidak miskin rata-rata lebih banyak mengakses terhadap internet dibanding kepala rumah tangga dengan status kemiskinan lainnya, dimana rumah tangga tidak miskin yang mengakses internet sebanyak $68 \%$, sedangkan rumah tangga rentan miskin $44 \%$, hampir miskin $42 \%$, miskin $60 \%$, dan sangat miskin $19 \%$. Adapun kepemilikan hp paling banyak dimiliki oleh rumah tangga tidak miskin yaitu sebesar $86 \%$, sedangkan terendah dimiliki rumah sangat miskin yaitu sebesar $68 \%$. Status tempat tinggal milik sendiri, pada rumah tangga tidak miskin rata-rata yang memilikinya sebanyak $63 \%$, Sedangkan pada rumah tangga rentan miskin, hampir miskin, miskin, dan sangat miskin rata-rata yang memilikinya secara berturut-turut $48 \%, 44 \%, 13 \%$, dan $46 \%$. Rumah tangga yang memiliki akses terhadap kredit usaha banyak dipakai oleh rumah tangga sangat miskin yaitu sebesar $42 \%$, sedangkan yang tidak memiliki akses sama sekali terhadap kredit usaha adalah rumah tangga sangat miskin.

Tabel 3.

Statistik Deskriptif Karakteristik Ekonomi

\begin{tabular}{|c|c|c|c|c|c|c|c|}
\hline $\begin{array}{c}\text { Status } \\
\text { Kemiskinan }\end{array}$ & $\begin{array}{l}\text { Sum } \\
\text { stats }\end{array}$ & $\begin{array}{c}\text { Status } \\
\text { Ketenaga- } \\
\text { kerjaan } \\
\text { KRT } \\
\text { (1=bekerja) }\end{array}$ & $\begin{array}{c}\text { Lapangan } \\
\text { Usaha } \\
\text { Utama } \\
\text { KRT } \\
\text { (1=sektor } \\
\text { dagang) } \\
\end{array}$ & $\begin{array}{c}\text { Akses } \\
\text { Terhadap } \\
\text { Internet } \\
\text { (1=akses } \\
\text { internet) }\end{array}$ & $\begin{array}{c}\text { Status } \\
\text { Kepemilikan } \\
\text { HP } \\
(1=\text { punya hp })\end{array}$ & $\begin{array}{c}\text { Status } \\
\text { Kepemilikan } \\
\text { Tempat } \\
\text { Tinggal } \\
\text { (1=milik } \\
\text { sendiri) } \\
\end{array}$ & $\begin{array}{c}\text { Akses } \\
\text { Terhadap } \\
\text { Kredit } \\
\text { Usaha } \\
\text { (1=akses } \\
\text { kredit) } \\
\end{array}$ \\
\hline \multirow[t]{2}{*}{ Tidak Miskin } & mean & 0,751 & 0,207 & 0,682 & 0,858 & 0,629 & 0,334 \\
\hline & $s d$ & 0,433 & 0,405 & 0,466 & 0,35 & 0,483 & 0,472 \\
\hline \multirow[t]{2}{*}{ Rentan Miskin } & mean & 0,803 & 0,282 & 0,437 & 0,775 & 0,479 & 0,408 \\
\hline & $s d$ & 0,401 & 0,453 & 0,499 & 0,421 & 0,503 & 0,495 \\
\hline \multirow[t]{2}{*}{ Hampir Miskin } & mean & 0,941 & 0,353 & 0,412 & 0,853 & 0,441 & 0,324 \\
\hline & $s d$ & 0,239 & 0,485 & 0,500 & 0,359 & 0,504 & 0,475 \\
\hline \multirow[t]{2}{*}{ Miskin } & mean & 0,867 & 0,333 & 0,600 & 0,733 & 0,133 & 0,333 \\
\hline & $s d$ & 0,352 & 0,488 & 0,507 & 0,458 & 0,352 & 0,488 \\
\hline \multirow[t]{2}{*}{ Sangat Miskin } & mean & 0,78 & 0,317 & 0,195 & 0,683 & 0,463 & 0,415 \\
\hline & $s d$ & 0,419 & 0,471 & 0,401 & 0,471 & 0,505 & 0,499 \\
\hline \multirow[t]{2}{*}{ Total } & mean & 0,764 & 0,224 & 0,634 & 0,843 & 0,598 & 0,342 \\
\hline & $s d$ & 0,425 & 0,417 & 0,482 & 0,364 & 0,491 & 0,475 \\
\hline
\end{tabular}

Sumber : Susenas 2018, diolah

Karakteristik sosial yang disajikan pada Tabel 4 meliputi tingkat pendidikan kepala rumah tangga yang diukur dari rata-rata lamanya bersekolah kepala rumah tangga, rata-rata kepemilikan jaminan kesehatan, dan rata-rata status kepala rumah tangga yang melakukan migrasi risen. Pada rumah tangga tidak miskin rata-rata lama sekolah dari kepala rumah tangga adalah 11 tahun, sedangkan pada rumah tangga rentan miskin, hampir miskin, miskin, dan sangat miskin rata-rata lama sekolah kepala rumah tangganya secara berurutan adalah 9,6 tahun, 7,8 tahun, 8,4 tahun dan 8,6 tahun. Hal tersebut berarti rata-rata tingkat pendidikan kepala rumah tangga tidak miskin berada pada jenjang SMA sederajat. 
Sementara itu, umumnya kepala rumah tangga rata-rata di Kota Bandung selama periode 2018 memiliki jaminan kesehatan diatas 50\%. Selanjutnya, kepala rumah tangga yang melakukan migrasi risen selama periode 2018 berasal dari rumah tangga tidak miskin sebanyak 4\%, rentan miskin $1 \%$, dan hampir miskin $2 \%$, rumah tangga miskin $6 \%$ dan rumah tangga sangat miskin mencapai 2 persen.

Tabel 4.

Statistik Deskriptif Karakteristik Sosial

\begin{tabular}{lcccc}
\hline \hline Status Kemiskinan & $\begin{array}{c}\text { Summary } \\
\text { statistics }\end{array}$ & $\begin{array}{c}\text { Lama Sekolah } \\
\text { KRT (tahun) }\end{array}$ & $\begin{array}{c}\text { Kepemilikan } \\
\text { Jaminan Kesehatan } \\
\text { (1=punya) }\end{array}$ & $\begin{array}{c}\text { Status KRT } \\
\text { migran risen } \\
\text { (1=migran) }\end{array}$ \\
\hline \hline Tidak Miskin & mean & 11,171 & 0,860 & 0,044 \\
Rentan Miskin & sd & 3,913 & 0,347 & 0,206 \\
& mean & 9,563 & 0,817 & 0,014 \\
Hampir Miskin & sd & 3,166 & 0,390 & 0,119 \\
Miskin & mean & 7,794 & 0,882 & 0,029 \\
& sd & 2,660 & 0,327 & 0,171 \\
Sangat Miskin & mean & 8,400 & 0,933 & 0,067 \\
Total & sd & 3,641 & 0,258 & 0,258 \\
& mean & 8,537 & 0,854 & 0,024 \\
& sd & 3,083 & 0,358 & 0,156 \\
\hline
\end{tabular}

Sumber : Susenas 2018, diolah

Pada regresi logistik, parameter yang dilihat pada uji Goodness of Fit adalah Pseudo $R^{2}$. Nilai Pseudo $R^{2}$ didasarkan pada perbedaan nilai maksimum loglikelihood suatu model tanpa dan dengan variabel independen. Nilai Pseudo $R^{2}$ adalah sebesar 0,1830. Hal ini mengindikasikan bahwa variabel independen hanya mampu menjelaskan variabel dependen sebesar 18,30 persen atau, hanya 18,30 persen dari variasi variabel tidak bebas yang dapat dijelaskan oleh model. Walaupun demikian, nilai Pseudo $R^{2}$ yang kecil tidak membuat suatu model dianggap tidak bagus. Hal ini dikarenakan, nilai Pseudo $R^{2}$ yang bernilai 0 sampai 1 bukan merupakan interpretasi yang alami melainkan tiruan untuk mengganti $R$-square OLS pada model logit. Lebih jelasnya dapat dilihat pada Tabel 5 berikut ini.

Pengujian signifikansi model secara keseluruhan dalam model regresi logit dilakukan melalui Likelihood-Ratio (LR). Hasil pengujian LR untuk setiap model yang digunakan dalam penelitian ini didapat dari hasil estimasi dengan memeriksa hasil Prob > chi2 (probabilitas LR Stat terhadap chi square) dibawah tingkat signifikansi $\alpha$, diketahui bahwa nilai probabilitas LR dalam model tersebut yaitu 0,0000. Hal ini menunjukkan bahwa semua variabel independen dalam semua model secara bersama-sama mempengaruhi variabel tidak bebasnya. Pengujian signifikansi parsial atau uji-z dilakukan untuk mengetahui pengaruh dari setiap variabel independen terhadap variabel dependen pada model regresi logit. Hasil uji ini menandakan bahwa untuk setiap variabel bebas yang uji-z nya signifikan, maka secara individu variabel tersebut mempengaruhi variabel tidak bebas. 
Tabel 5.

Hasil Estimasi Model Ordered Logit

\begin{tabular}{|c|c|c|c|c|c|}
\hline Variabel & $\begin{array}{c}\text { tidak } \\
\text { miskin } \\
\left(\mathbf{y}_{\mathrm{i}}=1\right)\end{array}$ & $\begin{array}{c}\text { rentan } \\
\text { miskin } \\
\left(y_{i}=2\right)\end{array}$ & $\begin{array}{c}\text { hampir } \\
\text { miskin } \\
\left(\mathbf{y}_{\mathrm{i}}=3\right)\end{array}$ & $\begin{array}{c}\underset{\left(y_{i}=4\right)}{\operatorname{miskin}} \\
\text {. }\end{array}$ & $\begin{array}{c}\text { sangat } \\
\text { miskin } \\
\left(\mathbf{y}_{\mathbf{i}}=5\right)\end{array}$ \\
\hline Usia & $\begin{array}{l}0.003 \\
(0.008)\end{array}$ & $\begin{array}{l}-0.001 \\
(0.003)\end{array}$ & $\begin{array}{l}-0.001 \\
(0.002)\end{array}$ & $\begin{array}{l}-0.000 \\
(0.001)\end{array}$ & $\begin{array}{l}-0.001 \\
(0.003)\end{array}$ \\
\hline Usia Kuadrat & $\begin{array}{l}0.000 \\
(0.000)\end{array}$ & $\begin{array}{l}-0.000 \\
(0.000)\end{array}$ & $\begin{array}{l}-0.000 \\
(0.000)\end{array}$ & $\begin{array}{l}-0.000 \\
(0.000)\end{array}$ & $\begin{array}{l}-0.000 \\
(0.000)\end{array}$ \\
\hline Jenis Kelamin $($ Perempuan $=1)$ & $\begin{array}{l}-0.015^{* *} \\
(0.033)\end{array}$ & $\begin{array}{l}0.005 * * \\
(0.011)\end{array}$ & $\begin{array}{l}0.003 * * \\
(0.007)\end{array}$ & $\begin{array}{l}0.002 * * \\
(0.003)\end{array}$ & $\begin{array}{l}0.005 * * \\
(0.011)\end{array}$ \\
\hline Status Menikah $($ ya $=1)$ & $\begin{array}{l}-0.283 * * \\
(0.115)\end{array}$ & $\begin{array}{l}0.099 * * \\
(0.040)\end{array}$ & $\begin{array}{l}0.060 * * \\
(0.026)\end{array}$ & $\begin{array}{l}0.029 * * \\
(0.014)\end{array}$ & $\begin{array}{l}0.095 * * \\
(0.041)\end{array}$ \\
\hline Jumlah Anggota Rumahtangga & $\begin{array}{l}-0.051 * * * \\
(0.006)\end{array}$ & $\begin{array}{l}0.018 * * * \\
(0.003)\end{array}$ & $\begin{array}{l}0.011 * * * \\
(0.002)\end{array}$ & $\begin{array}{l}0.005 * * * \\
(0.001)\end{array}$ & $\begin{array}{l}0.017 * * * \\
(0.003)\end{array}$ \\
\hline Status KRT $($ Bekerja=1) & $\begin{array}{l}0.068 * * \\
(0.035)\end{array}$ & $\begin{array}{l}-0.024 * \\
(0.012)\end{array}$ & $\begin{array}{l}-0.015^{* *} \\
(0.007)\end{array}$ & $\begin{array}{l}-0.007 * \\
(0.004)\end{array}$ & $\begin{array}{l}-0.023 * \\
(0.012)\end{array}$ \\
\hline Pekerjaan KRT (perdagangan $=1$ ) & $\begin{array}{l}0.033 * \\
(0.023)\end{array}$ & $\begin{array}{l}-0.012 * \\
(0.008)\end{array}$ & $\begin{array}{l}-0.007 * \\
(0.005)\end{array}$ & $\begin{array}{l}-0.003 * \\
(0.003)\end{array}$ & $\begin{array}{l}-0.011 * \\
(0.008)\end{array}$ \\
\hline Akses Internet & $\begin{array}{l}0.160 * * * \\
(0.024)\end{array}$ & $\begin{array}{l}-0.056^{* * *} \\
(0.010)\end{array}$ & $\begin{array}{l}-0.034 * * * \\
(0.007)\end{array}$ & $\begin{array}{l}-0.017 * * * \\
(0.004)\end{array}$ & $\begin{array}{l}-0.054 * * * \\
(0.012)\end{array}$ \\
\hline KRT Punya Smartphone & $\begin{array}{l}0.020 * \\
(0.030)\end{array}$ & $\begin{array}{l}-0.007 * \\
(0.011)\end{array}$ & $\begin{array}{l}-0.004 * \\
(0.006)\end{array}$ & $\begin{array}{l}-0.002 * \\
(0.003)\end{array}$ & $\begin{array}{l}-0.007 * \\
(0.010)\end{array}$ \\
\hline Status rumah (milik sendiri $=1$ ) & $\begin{array}{l}0.109 * * * \\
(0.022)\end{array}$ & $\begin{array}{l}-0.038 * * * \\
(0.008)\end{array}$ & $\begin{array}{l}-0.023 * * * \\
(0.006)\end{array}$ & $\begin{array}{l}-0.011 * * * \\
(0.004)\end{array}$ & $\begin{array}{l}-0.036 * * * \\
(0.009)\end{array}$ \\
\hline Akses Kredit Usaha $($ ya $=1)$ & $\begin{array}{l}0.010 * \\
(0.021)\end{array}$ & $\begin{array}{l}-0.004 * \\
(0.007)\end{array}$ & $\begin{array}{l}-0.002 * \\
(0.005)\end{array}$ & $\begin{array}{l}-0.001 * \\
(0.002)\end{array}$ & $\begin{array}{l}-0.003 * \\
(0.007)\end{array}$ \\
\hline Rata-rata lama sekolah (tahun) & $\begin{array}{l}0.011 * * * \\
(0.003)\end{array}$ & $\begin{array}{l}-0.004 * * * \\
(0.001)\end{array}$ & $\begin{array}{l}-0.002 * * * \\
(0.001)\end{array}$ & $\begin{array}{l}-0.001^{* * *} \\
(0.000)\end{array}$ & $\begin{array}{l}-0.004 * * * \\
(0.001)\end{array}$ \\
\hline Jaminan Kesehatan HH (ya = 1) & $\begin{array}{l}-0.012 \\
(0.029)\end{array}$ & $\begin{array}{l}0.004 \\
(0.010)\end{array}$ & $\begin{array}{l}0.003 \\
(0.006)\end{array}$ & $\begin{array}{l}0.001 \\
(0.003)\end{array}$ & $\begin{array}{l}0.004 \\
(0.010)\end{array}$ \\
\hline Migran & $\begin{array}{l}-0.043 \\
(0.052)\end{array}$ & $\begin{array}{l}0.015 \\
(0.018)\end{array}$ & $\begin{array}{l}0.009 \\
(0.011)\end{array}$ & $\begin{array}{l}0.004 \\
(0.006)\end{array}$ & $\begin{array}{l}0.014 \\
(0.017)\end{array}$ \\
\hline Beban Ketergantungan & $\begin{array}{l}-0.000 * \\
(0.001)\end{array}$ & $\begin{array}{l}0.000 * \\
(0.000)\end{array}$ & $\begin{array}{l}0.000 * \\
(0.000)\end{array}$ & $\begin{array}{l}0.000 * \\
(0.000)\end{array}$ & $\begin{array}{l}0.000 * \\
(0.000)\end{array}$ \\
\hline $\mathrm{N}$ & 997 & 997 & 997 & 997 & 997 \\
\hline
\end{tabular}

Keterangan :

Standard errors in parenthese

$*$ significant at $10 \%, * *$ significant at $5 \%, * * *$ significant at $1 \%$

Usia merupakan variabel yang menunjukkan usia dari kepala rumah tangga. Berdasarkan hasil estimasi model seperti terlihat pada Tabel 5 diketahui bahwa variabel usia memiliki arah positif namun tidak signifikan mempengaruhi status kemiskinan rumah tangga. Hasil penelitian ini sejalan 
dengan penelitian yang dilakukan oleh Mok., et al. (2007) bahwa usia kepala rumah tangga tidak signifikan dalam mempengaruhi status kemiskinan rumah tangga.

Jenis kelamin kepala rumah tangga perempuan di Kota Bandung menunjukkan hasil yang signifikan secara statistik pada tingkat 5 persen dan berpengaruh positif terhadap status kemiskinan. Berdasarkan hasil marginal effect-nya diketahui bahwa probabilitas rumah tangga akan meningkat pada status sangat miskin sebesar 0,5 persen, miskin sebesar 0,2 persen, hampir miskin sebesar 0,3 persen, dan rentan miskin sebesar 0,5 persen jika jenis kelamin kepala rumah tangganya perempuan. Hal ini dimungkinkan karena kepala rumah tangga perempuan kurang memiliki akses yang baik terhadap aset produktif, sehingga kurang produktif dan kurang meningkatkan pendapatan.

Temuan ini sejalan dengan temuan yang diperoleh Wulandari (2016) yang menyatakan bahwa kepala rumah tangga berjenis kelamin perempuan lebih beresiko menjadi miskin bila dibandingkan dengan kepala rumah tangga berjenis kelamin laki-laki. Hasil temuan lainnya menemukan bahwa jenis kelamin kepala rumah tangga signifikan mempengaruhi status kemiskinan rumah tangga, dimana kepala rumah tangga berjenis kelamin laki-laki memiliki kecenderungan untuk tidak terkatergori miskin (Geda, et al (2005). Hasil penelitian ini berbeda dengan temuan Mok., et al. (2007) dan Sekhampu (2013) yang menemukan bahwa jenis kelamin kepala rumah tangga tidak signifikan mempengaruhi status kemiskinan rumah tangga.

Status perkawinan kepala rumah tangga di Kota Bandung signifikan pada tingkat 5 persen mempengaruhi terhadap status kemiskinan rumah tangga. Adapun hasil marginal effect-nya menunjukkan bahwa kepala rumah tangga dengan status kawin cenderung berpeluang masuk ke dalam kategori rentan miskin sebesar 9,9 persen, hampir miskin 6 persen, miskin 2,9 persen atau sangat miskin sebesar 9,5 persen. Penelitian ini sejalan dengan hasil penelitian Geda, et al (2005) dan Epo (2010) menunjukkan bahwa status perkawinan kepala rumah tangga signifikan mempengaruhi status kemiskinan rumah tangga. Sedangkan temuan Mok, et al (2007); Sekhampu (2013); Cho \& Kim (2017) yang menunjukkan bahwa status perkawinan kepala rumah tangga tidak signifikan mempengaruhi status kemiskinan rumah tangga.

Hasil estimasi jumlah anggota rumah tangga di Kota Bandung signifikan pada level 1 persen mempengaruhi status kemiskinan rumah tangga di Kota Bandung. Adapun hasil marginal effectnya dapat diinterpretasikan bahwa setiap penambahan 1 orang anggota rumah tangga dapat meningkatkan peluang sebuah rumah tangga untuk terkategori sangat miskin sebesar 1,7 persen, miskin sebesar 0,5 persen, hampir miskin sebesar 1,1 persen, dan rentan miskin sebesar 1,8 persen. Hasil ini sesuai dengan penelitian yang dilakukan oleh Epo (2010), Sekhampu (2013) dan Wulandari (2016) yang menemukan bahwa semakin banyak anggota rumah tangga maka semakin besar kemungkinan mereka untuk jatuh miskin. Hal ini disebabkan oleh semakin meningkatnya jumlah anggota rumah tangga, maka pendapatan/pengeluaran per kapita yang didistribusikan di antara anggota rumah tangga akan semakin kecil. Dengan kata lain, semakin banyak anggota rumah tangga yang harus ditanggung, maka semakin berat beban ekonomi suatu rumah tangga dan menjadi tugas kepala rumah tangga. Sekhampu (2013) dan Rusdarti (2013) menunjukkan bahwa ukuran keluarga yang meningkat menunjukkan jumlah tanggungan yang lebih besar dengan jumlah penerima yang lebih sedikit dan hal ini dapat menyebabkan konsumsi lebih sedikit dan konsumsi per kapita lebih rendah.

Status ketenagakerjaan kepala rumah tangga signifikan terhadap status kemiskinan rumah tangga pada level 5 sampai 10 persen. Hasil marginal effectnya dapat diinterpretasikan bahwa setiap kepala rumah tangga yang bekerja akan menurunkan probabilitas rumah tangga untuk terkategori sangat miskin sebesar 2,3 persen, miskin sebesar 0,7 persen, hampir miskin 1,5 persen, rentan miskin 
2,4 persen. Temuan ini sesuai dengan penelitian Sekhampu (2013) yang menyatakan bahwa kepala rumah tangga yang bekerja akan mengurangi probabilitas rumah tangga tersebut terkategori miskin.

Kepala rumah tangga yang bekerja di sektor perdagangan besar dan eceran, reparasi mobil dan sepeda motor merupakan lapangan pekerjaan utama bagi masyarakat di Kota Bandung, hal ini terlihat dari distribusi PDRB Kota Bandung tahun 2016 atas harga berlaku yang berkontribusi sebesar 27,01 persen, sedangkan dari data Sakernas dalam Kota Bandung Dalam Angka 2017 yang menunjukkan bahwa sekitar 34 persen penduduk berumur 15 tahun ke atas yang bekerja memilih lapangan pekerjaan di sektor perdagangan. Berdasarkan hasil regresi menunjukkan bahwa variabel tersebut berarah negatif terhadap status kemiskinan rumah tangga walaupun secara statistik tidak signifikan.

Sementara itu, untuk melihat akses suatu rumah tangga terhadap teknologi informasi dan komunikasi digunakan variabel internet. Berdasarkan hasil estimasi model serta marginal effectnya diketahui bahwa variabel internet signifikan secara statistik sebesar 1 persen mempengaruhi status kemiskinan rumah tangga di Kota Bandung. Berdasarkan marginal effect-nya dapat diinterpretasikan bahwa rumah tangga yang mengakses internet akan menurunkan probabilitas rumah tangga untuk terkategori sangat miskin sebesar 5,4 persen, miskin sebesar 1,7 persen, hampir miskin sebesar 3,4 persen, dan rentan miskin sebesar 5,6 persen. Sebaliknya, akan meningkatkan probabilitas rumah tangga untuk terkategori tidak miskin sebesar 16 persen pada tingkat signifikansi 1 persen. Hasil penelitian ini sejalan dengan penemuan Widiyastuti (2015) yang menyatakan bahwa penetrasi internet berpengaruh secara signifikan dalam menurunkan laju kemiskinan. Perkembangan penggunaan internet mulai cukup banyak sejak tahun 2009 selanjutnya dari tahun ke tahun perkembangannya semakin pesat. Internet tidak sekedar alat komunikasi, tetapi juga media informasi dan pengetahuan sekaligus pengolahan data yang dapat dimanfaatkan untuk memperkuat ekonomi masyarakat. Kendati demikian, hambatan yang dimiliki oleh penduduk miskin menjadi penghalang untuk memperoleh impak penetrasi internet terhadap kemiskinan. Kenny (2002) berdasarkan penelitiannya menyatakan bahwa TIK (Teknologi Informasi dan Komunikasi) dimana internet termasuk di dalamnya merupakan salah satu alat yang dapat digunakan pemberdayaan dan penghasilan pendapatan di negara berkembang. TIK juga dapat bertindak sebagai perantara berkelanjutan dalam pengentasan kemiskinan.

Akses rumah tangga terhadap teknologi informasi dan komunikasi melalui kepemilikan HP signifikan terhadap status kemiskinan rumah tangga pada level 10 persen dan berarah negatif. Marginal effect-nya dapat diinterpretasikan bahwa kepala rumah tangga yang menguasai/memiliki hp akan menurunkan probabilitas rumah tangga untuk terkategori sangat miskin sebesar 0,7 persen, miskin sebesar 0,1 persen, hampir miskin sebesar 0,2 persen, dan rentan miskin sebesar 0,4 persen pada tingkat signifikansi 10 persen. Sebaliknya, akan meningkatkan probabilitas rumah tangga untuk terkategori tidak miskin sebesar 1 persen pada tingkat signifikansi 1 persen. Hasil temuan ini mengindikasikan bahwa rumah tangga yang yang memiliki smart phone (HP) efektif menurunkan tingkat kemiskinan, terutama status sangat miskin dengan dengan pengeluaran perkapita per bulan < 0,8 garis kemiskinan. Penemuan ini sesuai dengan temuan sebelumnya (Widiyastuti, 2015 ; Rini \& Sugiharti, 2016), yang menemukan bahwa rumah tangga dengan akses terhadap telekomunikasi signifikan dan memiliki efek negatif pada kemungkinan menjadi orang miskin. Ini berarti bahwa rumah tangga yang memiliki HP (akses terhadap telekomunikasi) akan menurunkan probabilitas miskin. Spence \& Smith (2010) menyatakan bahwa penggunaan HP memungkinkan dan memfasilitasi peluasan pasar, sosial bisnis, dan layanan publik yang dapat berdampak pada pengentasan kemiskinan. 
Hasil penelitian menemukan bahwa variabel kepemilikan aset terhadap kemiskinan rumah tangga, pada penelitian ini dilihat dari kepemilikan bangunan tempat tinggal khususnya yang memiliki rumah sendiri signifikan pada tingkat 1 persen terhadap probabilitas status kemiskinan rumah tangga. Adapun hasil marginal effect-nya dapat diinterpretasikan bahwa setiap rumah tangga yang memiliki rumah sendiri akan menurunkan probabilitas rumah tangga terkategori sangat miskin sebesar 3,6 persen, miskin sebesar 0,1 persen, hampir miskin sebesar 2,3 persen, dan rentan miskin sebesar 3,8 persen pada tingkat signifikansi 1 persen. Sebaliknya, akan meningkatkan probabilitas rumah tangga terkategori tidak miskin sebesar 10,9 persen pada tingkat signifikansi 1 persen. Dengan demikian, dapat diinterpretasikan bahwa rumah tangga di Kota Bandung yang memiliki rumah sendiri akan menurunkan probabilitasnya untuk terkategori sangat miskin, miskin, hampir miskin, dan rentan miskin. Penelitian ini sejalan dengan temuan Sa'diyah, Yufi \& Arianti (2012), bahwa kepemilikan aset yaitu kepemilikan bangunan tempat tinggal berpengaruh terhadap menurunnya probabilitas rumah tangga untuk terkategori miskin.

Akses terhadap kredit usaha, baik akses anggota rumah tangga yang pernah melakukan kredit terkait usaha, baik dari PNPM, Program Pemerintah, Kredit Usaha Rakyat (KUR), Program Bank selain KUR, Program Koperasi, Perseorangan, atau lainnya, dalam setahun terakhir signifikan pada level 10 persen terhadap probabilitas status kemiskinan rumah tangga di Kota Bandung. Marginal effect-nya dapat diinterpretasikan bahwa rumah tangga yang memiliki akses terhadap kredit usaha akan menurunkan probabilitas rumah tangga pada status sangat miskin sebesar 0,3 persen pada tingkat signifikansi 10 persen, status miskin sebesar 0,1 persen pada tingkat signifikansi 10 persen, status hampir miskin sebesar 0,2 persen pada tingkat signifikansi 10 persen, dan status rentan miskin sebesar 0,4 persen pada tingkat signifikansi 10 persen. Sebaliknya, akan meningkatkan probabilitas rumah tangga pada status tidak miskin sebesar 1 persen pada tingkat signifikansi 10 persen. Hasil penelitian ini sejalan dengan hasil penelitian Rini \& Sugiharti (2016) bahwa rumah tangga yang mengakses kredit usaha memiliki kemungkinan berstatus miskin lebih rendah daripada yang tidak mengakses. Rini \& Sugiharti (2016) menyatakan bahwa kemudahan akses terhadap kredit dapat membantu keluarga miskin untuk memulai beberapa aktivitas yang menghasilkan pendapatan, seperti membuka toko, membuat kerajinan-kerajinan tangan, menjahit, dan lain-lain. Dengan demikian, keluarga tersebut akan mampu meningkatkan kesejahteraannya dan membantunya keluarga dari kemiskinan.

Tingkat pendidikan kepala rumah tangga yang diukur dari lama sekolah signifikan pada tingkat 1 persen. Artinya, bahwa untuk penambahan satu tahun lama sekolah kepala rumah tangga akan menurunkan probabilitas rumah tangga terkategori sangat miskin sebesar 0,4 persen, miskin sebesar 0,1 persen, hampir miskin sebesar 0,2 persen, dan rentan miskin sebesar 0,4 persen pada tingkat signifikansi 1 persen. Sebaliknya, akan meningkatkan probabilitas rumah tangga terkategori tidak miskin sebesar 1,1 persen pada tingkat signifikansi 1 persen. Hal ini sesuai dengan temuan sebelumnya (Geda, et al, 2005; Mok., et al, 2007; Epo, 2010; Wulandari, 2016). Todaro (2015) mengatakan bahwa rumah tangga dengan kepala rumah tangga yang memainkan peran penting dalam setiap pengambilan keputusan, maka tingkat pendidikan kepala rumah tangga akan berpengaruh terhadap pola pikir dalam pengambilan keputusan tersebut. Selain itu, pendidikan orang tua juga terbukti memainkan peran penting dalam pengambilan keputusan pendidikan anak. World Bank (2007), menyatakan bahwa kemiskinan memiliki kaitan yang sangat erat dengan pendidikan yang tidak memadai. Sama halnya dengan temuan di negara-negara lain, capaian jenjang pendidikan yang lebih tinggi berkaitan dengan konsumsi rumah tangga yang lebih tinggi pula. Di daerah perkotaan, kepala rumah tangga dengan tingkat pendidikan sekolah menengah atas (SMA) memiliki korelasi 
dengan tingkat konsumsi yang 33 persen lebih tinggi dibandingkan dengan kepala rumah tangga yang tidak berpendidikan. Peningkatan konsumsi yang berkorelasi dengan pendidikan khususnya terlihat mencolok pada lulusan universitas, baik di daerah perkotaan maupun daerah pedesaan (masing-masing 72 persen dan 45 persen). Berbeda dengan temuan Sekhampu (2013) bahwa lama sekolah kepala rumah tangga berhubungan negatif dengan status kemiskinan, namun secara statistik tidak signifikan. Ini menunjukkan bahwa lama sekolah kepala rumah tangga tidak sepenuhnya menjelaskan status kemiskinan rumah tangga.

Selanjutnya, kepemilikan jaminan kesehatan suatu rumah tangga tidak signifikan terhadap probabilitas status kemiskinan rumah tangga. Artinya kepemilikan jaminan kesehatan rumah tangga tidak mempengaruhi secara signifikan terhadap status kemiskinan rumah tangga di Kota Bandung. Hal yang sama terjadi pada kepala rumah tangga yang berstatus migrasi risen tidak signifikan namun berpengaruh negatif terhadap probabilitas status kemiskinan rumah tangga. Artinya, kepala rumah tangga migran ataupun bukan migran tidak mempengaruhi secara signifikan terhadap status kemiskinan rumah tangga di Kota Bandung. Penelitian ini berbeda dengan hasil temuan Wulandari (2016) dan Zulfachri, Puad \& Wan (2017). Wulandari (2016) menyatakan bahwa rumah tangga bukan migran lebih beresiko menjadi miskin dibandingkan dengan rumah tangga migran, sedangkan rumah tangga yang melakukan migrasi risen berpeluang terkategori miskin lebih besar dibandingkan dengan rumah tangga yang tidak melakukan migrasi risen (Zulfachri, Puad \& Wan)

Faktor lain yang juga berpengaruh terhadap tingkat kemiskinan adalah rasio ketergantungan penduduk. Dalam hal ini, semakin tinggi persentase nilai ketergantungan penduduk maka semakin tinggi pula beban yang harus ditanggung penduduk yang produktif untuk menanggung penduduk yang belum produktif dan tidak produktif lagi. Beban ketergantungan berpengaruh negatif dan signifikan pada tingkat 10 persen terhadap probabilitas status kemiskinan rumah tangga, menurut data susenas 2018. Hal tersebut didukung oleh penelitian yang dilakukan Knowles (2002), yang menyatakan bahwa meningkatnya rasio ketergantungan akan meningkatkan proporsi populasi yang hidup dalam kemiskinan. Angka kelahiran yang tinggi berimplikasi pada tingginya rasio ketergantungan.

\section{SIMPULAN DAN SARAN}

Ada beberapa temuan dari studi ini yang dapat disimpulkan. Hasil penelitian menunjukkan bahwa variabel karakteristik demografi yang berpengaruh signifikan dan positif terhadap status kemiskinan rumah tangga di Kota Bandung adalah kepala rumah tangga berjenis kelamin perempuan, kepala rumah tangga berstatus kawin dan ukuran rumah tangga dan beban ketergantungan. Sementara itu, karakteristik ekonomi yaitu akses rumah tangga terhadap internet, kepemilikan handphone (HP), kepemilikan rumah tinggal sendiri, dan akses terhadap kredit usaha berpengaruh negatif dan signifikan terhadap status kemiskinan rumah tangga di Kota Bandung. Terakhir, karakteristik sosial yang berpengaruh negatif terhadap status kemiskinan rumah tangga di Kota Bandung yaitu variabel tingkat pendidikan sekolah yang diukur dari lama sekolah.

\section{REFERENSI}

Badan Pusat Statistik Kota Bandung. (2018). Kota Bandung Dalam Angka. Badan Pusat Statistik Kota Bandung, Bandung. 
Badan Pusat Statistik. (2019). Profil Kemiskinan di Indonesia Maret 2019. Berita Resmi Statistik, No. 66/07/Th. XIX, 18 Juli 2016.

Bappenas (2014). Perlindungan Sosial di Indonesia:Tantangan Dan Arah Ke Depan. Kementerian Perencanaan Pembangunan Nasional/Badan Perencanaan Pembangunan NasionalDirektorat Perlindungan dan Kesejahteraan Masyarakat. Tersedia di

https://www.bappenas.go.id/files/5114/2889/4558/Perlindungan_Sosial_di_Indonesia-

Tantangan_dan_Arah_ke_Depan.pdf (di Akses 20 Mei 2019)

Bogale., A., Hagedorn., K \& Korf., B. (2005). Determinants of Poverty in Ethiopia. Quarterly, Journal of International Agriculture 44(44), 101-120.

Cho, S \& Kim, T. (2017). Determinants of Poverty Status in Rwanda. African Development Review, 29(2), 2017, 337-349. https://doi.org/10.1111/1467-8268.12260

Inna Dariwardani., N.M. (2014). Analisis Dinamika Kemiskinan (Poverty Dynamics) di Bali Berdasarkan Data Susenas Panel 2008 - 2010. Jurnal Ekonomi Kuantitatif Terapan 7(1),. https://doi.org/10.24843/JEKT.2014.v07.i01.p02

Epo, B (2010) Determinants of Poverty in Cameroon: A Binomial and Polychotomous Logit Analysis (February 13, 2010). Tersedia di SSRN: https://ssrn.com/abstract=1424672 http://dx.doi.org/10.2139/ssrn.1424672 (di Akses 8 Juli 2019)

Griggs, D., Stafford-Smith, M., Gaffney, O., Rockstr??m, J., ??hman, M. C., Shyamsundar, P., ... Noble, I. (2013). Policy: Sustainable development goals for people and planet. Nature. 492, 305-307

Geda, A., et al. (2005). Determinants of Poverty in Kenya: A Household Level Analysis. Economics Working Papers. Paper 200544, University of Connecticut, Department of Economics.

Haughton, J \& Khandker, S R. (2012). Pedoman Tentang Kemiskinan dan Ketimpangan (Handbook on Poverty and Inequality. Salemba Empat, Jakarta. ISBN/ISSN : 9789790611511

Isdijoso, W., Suryahadi, A., \& Akhmadi. (2016). Penetapan Kriteria dan Variabel Pendataan Penduduk Miskin yang Komprehensif dalam Rangka Perlindungan Penduduk Miskin di Kabupaten/Kota. The SMERU Research Institute.

Kates, R. W., Parris, T. M., \& Leiserowitz, A. A. (2005). What is sustainable development? Goals, indicators, values, and practice. Environment, 47(3), 8-21. https://doi.org/10.1080/00139157.2005.10524444

Kenny, C. (2002). Information and Communication Technologies for Direct Poverty Alleviation: Cost and Benefits. Development Policy Review, 2002, 20 (2) : 141 - 157.

Mok. T.Y., Gan, C. \& Sanyal A. (2007). The Determinants of Urban Household Poverty in Malaysia. Journal of Social Sciences. 3 (4) : 190-196.

Moran, D. D., Wackernagel, M., Kitzes, J. A., Goldfinger, S. H., \& Boutaud, A. (2008). Measuring sustainable development - Nation by nation. Ecological Economics, 64(3), 470-474. https://doi.org/10.1016/j.ecolecon.2007.08.017

Panuluh., S \& Fitri., M,K (2016). Perkembangan Pelaksanaan Sustainable Development Goals (SDGs) di Indonesia September 2015-September 2016, Briefing paper 02. Tersedia di https://www.sdg2030indonesia.org/an-component/media/upload-book/Briefing paper_No_1_SDGS_2016-Meila_Sekar.pdf. (di Akses 8 Juli 2019)

Rini, A.S \& Sugiharti, L. (2016). Faktor-faktor Penentu Kemiskinan di Indonesia: Analisis Rumah Tangga. Jurnal Ilmu Ekonomi Terapan. 01(2): 17-33 ISSN 2085-4617.

Rusdarti.,R \& Sebayang., L,K (2013). Faktor-Faktor yang Mempengaruhi Tingkat Kemiskinan di Provinsi Jawa Tengah. Jurnal Economia, 9(1). https://doi.org/10.21831/economia.v9i1.1371

Sachs, J. D. (2012). From millennium development goals to sustainable development goals. The Lancet.379(12). 2206-2211. https://doi.org/10.1016/S0140-6736(12)60685-0

Sa'diyah, Yufi., H \& Arianti, F. (2012). Analisis Kemiskinan Rumah Tangga Melalui Faktor-Faktor yang Mempengaruhinya di Kecamatan Tugu Kota Semarang. Diponegoro Journal Of Economics, 1(1), 23373814.

Sekhampu, T.,J. (2013). Determinants of Poverty in a South African Township. J Soc Sci, 34(2): 145-153. https://doi.org/10.1080/09718923.2013.11893126

SMERU (2017). Dari MDGs ke SDGs: Memetik Pelajaran dan Menyiapkan Langkah Konkret. Buletin SMERU No. 2/2017. The SMERU Research Institute.

Spence, R., \& Smith., M.L. (2010). ICT, Development, and Poverty Reduction: Five Emerging Stories. USC Annenberg School for Communication \& Journalism, Volume 6, SE, Special Edition 2010, 11-17.

Todaro, M, P \& Smith, S.C. (2015). Economic Development, 12th Edition. Pearson Education.

Widiyastuti, I. (2015) Analisis Runtun Waktu dalam Pengujian Pengaruh TIK terhadap Penurunan Laju Kemiskinan di Indonesia. Jurnal IPTEK-KOM. 17(1): 19-30. 
Wulandari, N, S (2016). Faktor-Faktor Yang Mempengaruhi Kemiskinan Rumah Tangga Di Kota Kendari Tahun 2014. Jurnal Progres Ekonomi Pembangunan.1(1): 2502-5171.

Zulfachri, B., Puad, Ahmad \& Wan., A.A. (2017). Pengaruh Migrasi Risen terhadap Tingkat Kesejahteraan di Provinsi Kepulauan Riau. Jurnal Samudra Ekonomi dan Bisnis. 8(2).1-13. 